\title{
Health care for people with disabilities in a rural setting under the perspective of community agents
}

Atenção à saúde de pessoas com deficiência em cenário rural sob perspectiva dos agentes comunitários Atención a la salud de personas con discapacidad en escenario rural bajo perspectiva de los agentes comunitarios

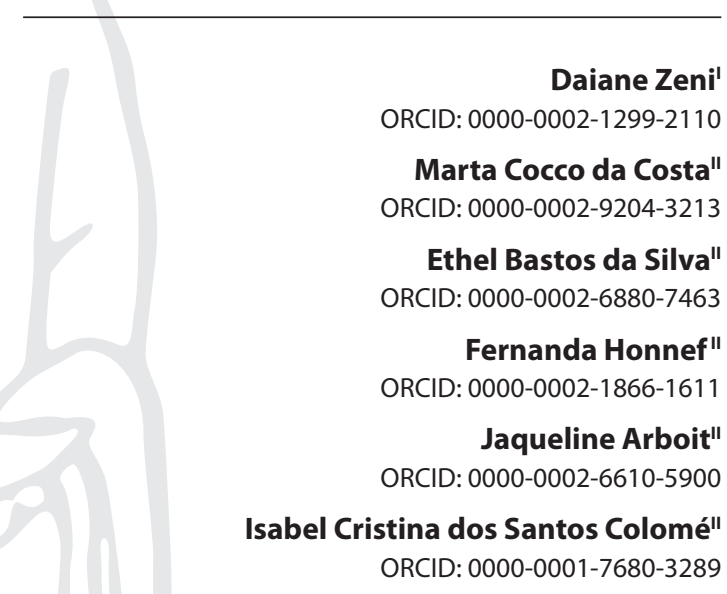

'Universidade Federal de Santa Maria. Palmeira das Missões, Rio Grande do Sul, Brazil. "Universidade Federal de Santa Maria. Santa Maria, Rio Grande do Sul, Brazil.

How to cite this article:

Zeni D, Costa MC, Silva EB, Honnef F, Arboit J, Colomé ICS Health care for people with disabilities in a rural setting under the perspective of community agents.

Rev Bras Enferm. 2020;73(6):e20190204. doi: http://dx.doi.org/10.1590/0034-7167-2019-0204

\section{Corresponding author:}

Marta Cocco da Costa E-mail:marta.c.c@ufsm.br

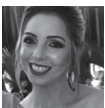

EDITOR IN CHIEF: Antonio José De Almeida Filho ASSOCIATE EDITOR: Andrea Bernardes

Submission: 06-06-2019

Approval: 03-13-2020

\section{ABSTRACT}

Objective: To understand how health care for people with disabilities in rural settings occurs according to the perspective of Community Health Agents. Methods: Qualitative approach study in which 13 Community Health Agents participated. Data collection took place through semi-structured interviews. The data were systematized and analyzed by Minayo's content analysis. Results: Some weaknesses and barriers make people with disabilities living in rural settings, invisible and distant from comprehensive and equitable health care. The weaknesses are related to unprepared CHAs and the inefficient qualifications to serve this population. The barriers to seeking comprehensive care are particularly physical, economic, geographical, and infrastructural. Final Considerations: It is imperative to give visibility to people with disabilities in the rural context, considering the singularities of this place, in order to enhance sensitive and welcoming care provided by health services.

Descriptors: Disabled Persons; Rural Population; Community Health Workers; Nursing; Health Care.

\section{RESUMO}

Objetivo: Compreender como ocorre a atenção à saúde de pessoas com deficiência residentes em cenários rurais na perspectiva de Agentes Comunitários de Saúde. Métodos: Estudo de abordagem qualitativa do qual participaram 13 Agentes Comunitários de Saúde. A coleta de dados ocorreu mediante entrevistas semiestruturadas. Os dados foram sistematizados e analisados pela análise de conteúdo de Minayo. Resultados: Existem fragilidades e barreiras que deixam as pessoas com deficiência residentes em cenário rural invisibilizadas e distantes de uma atenção integral e equitativa à saúde. As fragilidades relacionam-se com o despreparo dos ACSs e as ineficientes qualificações para atender essa população. Já as barreiras para a busca por uma atenção integral são especialmente físicas, econômicas, geográficas e infraestruturais. Considerações Finais: É premente dar visibilidade às pessoas com deficiência no contexto rural considerando as singularidades desse espaço, para potencializar um cuidado sensível e acolhedor junto aos serviços de saúde.

Descritores: Pessoas com Deficiência; População Rural; Agentes Comunitários de Saúde; Enfermagem; Atenção à Saúde.

\section{RESUMEN}

Objetivo: Comprender como acorre la atención a la salud de personas con discapacidad residentes en escenarios rurales en la perspectiva de Agentes Comunitarios de Salud. Métodos: Estudio de abordaje cualitativo del cual participaron 13 Agentes Comunitarios de Salud. La recogida de datos ocurrió mediante entrevistas semiestructuradas. Los datos han sido sistematizados y analizados por el análisis de contenido de Minayo. Resultados: Hay fragilidades y barreras que dejan las personas con discapacidad residentes en escenario rural invisibilizadas y distantes de una atención integral y equitativa a la salud. Las fragilidades se relacionan con la falta de preparación de los ACSs y las ineficientes calificaciones para atender esa población. Ya las barreras para la búsqueda por una atención integral son especialmente físicas, económicas, geográficas y infraestructurales. Conclusión: Es apremiante dar visibilidad a las personas con discapacidad en contexto rural considerando las singularidades de eso espacio, para potencializar un cuidado sensible y acogedor junto a los servicios de salud.

Descriptores: Personas con Discapacidad; Población Rural; Agentes Comunitarios de Salud; Enfermería; Atención a la Salud. 


\section{INTRODUCTION}

According to the World Health Organization, it is estimated that $15 \%$ of the world population has some disability (1). In Brazil, according to the 2010 Census, approximately $6.7 \%$ of the population has some type of severe sensory, physical, or intellectual disability ${ }^{(2)}$. The concept of people with disabilities adopted by the Health Policy for People with Disabilities was updated to be conceived under a dynamic and biopsychosocial nature, following the International Convention on the Rights of Persons with Disabilities and its Optional Protocol in Brazil, in $2009^{(3)}$. In this sense, people with disabilities are those who have long-term physical, mental, intellectual or sensory impairments, which, in interaction with various barriers, can obstruct their full and effective participation in society on equal terms with other people ${ }^{(4)}$.

People with disabilities have different health demands. However, barriers - factors that hinder access and accessibility to services, whether physical, emotional, or structural - can lead to negative health outcomes and widen disparities between people with disabilities and the general population ${ }^{(5)}$.

Thus, governments have developed policies, laws, and decrees with recommendations and guidelines for health care services in order to overcome the barriers mentioned above. Among these, at the national level, there is the Política Nacional de Saúde da Pessoa com Deficiência (PNSPD - National Health Policy for Persons with Disabilities), aimed at including people with disabilities in the entire Sistema Único de Saúde (SUS-Unified Health System) service network ${ }^{(6)}$.

Another government action instituted was the publication of Directive 793, of April 24, 2012, which created the Care Network for People with Disabilities. This ordinance has the objective of expanding access, qualifying care within the scope of SUS, promoting linking of people with disabilities, ensuring articulation, and integrating points of care, considering regional demands and territorial arrangements. Thus, this action intends that health care focus on the reality of the territory sustained by unique therapeutic projects, expanding the possibilities of equity and comprehensive care for people with disabilities ${ }^{(7)}$.

To reinforce the state's commitment to ensuring the right to health of people with disabilities, Law No. 13,146, of July 6, 2015, seeks to guarantee universal and equal access at all levels of complexity, through SUS ${ }^{(8)}$. Moreover, at the international level, the Sustainable Development Goals reiterate the importance of access to health with quality and equity in health care services $s^{(9-10)}$.

National and international policies, when truly incorporated into services, can enable access opportunities, to the care network, for people with disabilities who live in rural settings. In this perspective, the rural area is defined based on political-administrative criteria that consider urban any city seat characterized by constructions, streets, intense human occupation, and areas affected by transformations resulting from urban development. Thus, the rural area is qualified based on the population level, the predominance of agricultural activities, and political-administrative delimitation ${ }^{(11)}$.

When viewing the complexity of the health of people with disabilities in rural settings, in addition to the barriers arising from the geographical characteristics of this scenario, these people face an extensive set of information and financial barriers to access health care ${ }^{(12)}$. Rural populations are not covered by specific programs and depend on services concentrated in urban settings. Also, the health of people with disabilities in these settings is influenced by the particularities of their context. However, the care directed to them often disregards these aspects and focuses on the biomedical model. That is, health professionals in Primary Health Care (PHC) disregard the sociocultural singularities of users and use this model based on biological characteristics, directly influencing the service's resolvability ${ }^{(13)}$.

From the aspects presented, it appears that there are health vulnerabilities in people with disabilities living in rural settings. This fact occurs, in the programmatic dimension, due to the absence of public policies directed to the specificities of these people. In the individual dimension, it happens due to the lack of information from these people and their inability to operate them in their daily lives; and in the social dimension, due to the inability to obtain information and influence socially and politically to achieve free expression, security, and protection ${ }^{(14)}$. Corroborating this statement, review that sought to identify the factors that affect access to PHC services in rural areas highlighted human and infrastructure resources, geographical distances and difficulties with transportation as unfavorable factors for people with disabilities in the rural setting accessing the services ${ }^{(9)}$.

In order to overcome these barriers and connect rural settings to health services, there is the work of a Community Health Agent (CHA). Within the PHC, knowing the reality in which people with disabilities are inserted is part of the process work area of the CHA, which simultaneously integrates the health team and the local community. Thus, these professionals have a link with the latter, sharing the same difficulties of the population that they follow ${ }^{(15)}$.

In the CHA's routine, the main activity is home visits, which include the monitoring of the health conditions of families in the team's territorial area and the active search for unique situations. During visits, CHAs register family members and guide the use of available health services ${ }^{(16-17)}$. Besides, they have the possibility of identifying family members with a disability, although they have limitations in specifying the type and characteristics of it ${ }^{(18)}$.

Although equity in the care of people with disabilities is being discussed internationally, there are still gaps for it to be put into practice. That is because the biopsychosocial concepts present in national and international political agendas and attributed to people with disabilities encounter barriers to transcend health care practices, which are still fragmented and based on biological aspects. In this sense, understanding how care for people with disabilities is carried out in the rural setting from the perspective of $\mathrm{CHA}$ will make it possible to recognize limits and challenges to be overcome for the comprehensive care of this population in this unique setting.

\section{OBJECTIVE}

To understand how health care for people with disabilities in rural settings occurs according to the perspective of Community Health Agents.

\section{METHODS}

\section{Ethical aspects}

The research project was approved by the Research Ethics Committee of the Federal University of Santa Maria, following 
the recommendations expressed in Resolution 466/12 of the National Health Council, which deals with research with human beings. Then, the participants were individually informed about the objectives, method, risks, and benefits of the research, through the reading and explanation of the Free and Informed Consent Form. All participants signed the form in duplicate, one copy remaining with them and the other with the responsible researcher. The anonymity of the participants was guaranteed by using the abbreviation $\mathrm{CHA}$, followed by a cardinal number corresponding to the order of the interviews.

\section{Theoretical-methodological framework and type of study}

A descriptive study with a qualitative approach, which is applied to the study of history, relationships, representations, perceptions, and opinions resulting from the view that humans have of themselves, their ways of living and building their artifacts, in addition to of their feelings and thoughts ${ }^{(19)}$. The study was guided by the consolidated criteria for reporting qualitative research (COREQ).

\section{Methodological procedures}

\section{Study scenario}

The study was carried out in four municipalities located in the northwest region of the state of Rio Grande do Sul, Brazil, which had a rural population larger than urban and coverage of Community Health Agents.

\section{Data source}

The participants were 13 Community Health Agents who comprised the teams of Estratégias de Saúde da Família rurais (ESF-rural Family Health Strategies) in the study's municipalities. The inclusion criteria were integrating ESF teams that served the rural communities of the municipalities and being in the service for more than six months. The exclusion criterion was to be on leave of any nature or vacation.

Regarding the characteristics of the participants, $77 \%$ were female, and $23 \%$ male and had a mean age of 36.9 years old. As for education, $69.2 \%$ had completed high school; $23.1 \%$, complete higher education; $7.7 \%$, complete elementary school. The average training time was 5.3 years and length of time as a CHA 6.6 years.

\section{Data collection and organization}

To collect the data, first, we contacted those responsible for the services, such as health secretary or nurse responsible for the ESF in each of the study's municipalities. This contact aimed to present the project, organize the production of data, and meet the ESFs to perform data collection later.

Data were collected through semi-structured interviews conducted individually, which were guided by a script containing closed questions about the sociodemographic and training characteristics of the participants and open questions about how care for people with disabilities living in rural settings occurs.
The interviews were previously scheduled with each participant and carried out in the ESF unit in which they were linked, in a room reserved for data collection in order to guarantee privacy. They were recorded to ensure authentic material for analysis. Data collection took place between January and February of 2018 , and the organization of the data ended when the internal logic of the object of study was understood ${ }^{(20)}$.

\section{Data Analysis}

The empirical material from the interviews was submitted to the Content Analysis technique. Thus, three steps were followed: Pre-analysis; Exploration of the material; and Treatment of results, inference, and interpretation.

In the Pre-analysis, a skimming of the interviews was carried out to get to know the initial ideas of the empirical material and to appropriate its content ${ }^{(19)}$.

In the exploration of the material, through exhaustive reading, the similar ideas contained in it were sought and grouped, identifying the nuclei of meaning of the text. Then, the cores of meaning were reread and grouped, from which emerged the category "Health care in rural settings for people with disabilities under the perspective of Community Health Agents," with two cores of meaning: Professional biological concepts, limited and (un)qualified; and Barriers to access to health care.

In the third stage, "Interpretation of results, inference, and interpretation," inferences and interpretations about the results were proposed, resuming the objective of the investigation ${ }^{(19)}$.

\section{RESULTS}

\section{Health care in rural settings for people with disabilities under the perspective of Community Health Agents}

\section{Professional biological concepts, limited and (un)qualified}

The views of the $\mathrm{CHA}$ influence the care provided to people with disabilities in rural settings. When they conceive people with disabilities from a restricted view, physical and mental disabilities end up making other types of disabilities invisible.

It depends on whether it is mental disability or physical disability [...] people think that disability is only physical, but there is also mental disability. (CHA 5)

There is a girl aged 18, [...] who has a mental disability. (CHA 2)

In my area [...] There is a girl who was born [disabled] [...] she uses a wheelchair, she doesn't express herself, she doesn't speak anything. (CHA 1)

\section{[...] in my area, there are two autistic children. (CHA 4)}

Another aspect is the conception that there are no differences between people with disabilities and people without disabilities. This aspect makes people with disabilities invisible and keeps them away from health care, based on expanded care and their needs.

[...] [the disabled] is a normal person; for me, there is no difference. (CHA 9) 
In addition to these conceptions, the incipient knowledge of public policies aimed at people with disabilities was also identified, since the CHAs mostly cited one policy in their speeches, ignoring the existence of the others.

Policies I don't know what is [...] I won't know how to answer you about politics. (CHA 3)

[...] I don't have much knowledge. I know there are in schools [...] teachers have been implanted to take care of children who have problems [referring to disability]; this is a policy. (CHA 4)

The CHAs also reported having little knowledge about care in the care network for people with disabilities in rural settings and related this to the lack of training. Thus, they evidenced the need for changes in care for this population group.

Once, some people came to talk about people with disabilities, that there is a place where you can get a wheelchair [...], but they only said that [...]. (CHA 12)

Once we had a lecture that talked a little bit with the Coordination Office [...], they brought a list for us of all types of prostheses that people are entitled to. But I see a lot of difficulties. (CHA 6)

Another aspect mentioned by the study participants was the lack of support from the services of the care network for people with disabilities in the municipalities where they work. They assist the disabled with actions limited to communicating situations to other professionals in the health network, in an attempt to solve cases, but are unsuccessful.

[...] There should be more support for these people, but as far as possible, we do what we can [...] I as an ESF, health agent, we do what we can [...] there is a huge lack of support in our municipality in this sense of health. (CHA 5)

This [referring to a situation] of blind person I tried to speak one by one, I spoke to the psychologist, I spoke to other people too, because they have more knowledge than us [...] Until now nothing happened. (CHA 12)

\section{Barriers to access to health care}

The CHAs in this study point out the attitude of family members of people with disabilities as access barriers to the specialized care network, who, due to fear and lack of knowledge about the functioning of the Associações de Pais e Amigos dos Excepcionais (APAE- Association of Parents and Friends of Exceptional People), do not take their children. Furthermore, they reveal the difficulty of transportation, which may be due to the disability and the absence of auxiliary resources such as wheelchairs or crutches.

Here there is the Associação de Pais e Amigos dos Excepcionais [APAE] [...] from my area; I think only three come [...] usually mothers are afraid to send their children, afraid of people not taking good care of them [...] it's difficult to understand, it's lack of information. (CHA 4)

[...] there are people who need a cane, and we need a doctor's prescription, but these people cannot come [at the service] because they are from the countryside. (CHA 6)
The barriers imposed by the economic conditions of people and their families, as well as transportation difficulties, also hinder access to health services, APAE, and specialized services, given the geographical distance. This condition reinforces the isolation of people with disabilities in rural settings.

Even the difficulty of traveling, of going to the clinic, of coming to get medicines [...] the difficulty is significant because the majority are poor people who are unable to travel and come. (CHA 7)

\section{DISCUSSION}

The analysis of the data in this study made it possible to understand, under the perspective of the CHAs, how care for people with disabilities occurs in rural settings, making it possible to identify gaps between this care and the recommendations of public policies; in addition to situations that characterize social and programmatic vulnerability, which are evidenced by the difficulties in qualified health care.

The health care of people is influenced by the cultural and social aspects of each scenario, which are present in the reports about the CHAs' conceptions about people with disabilities. Thus, when professionals conceive people with disabilities from physical and mental aspects, they reveal conceptions based on the curative and biomedical model, although comprehensive care for people with disabilities includes one of the guidelines of the National Health Policy for the Person with Disabilities ${ }^{(6)}$.

The results of a study point out that the attention to people with disabilities centered on biological dimensions, often disregarding the other intrinsic elements of these people's lives, is configured as a limitation ${ }^{(9)}$, corroborating these findings. When considering only biological aspects, there is a fragmentation of care and disregard for the integrality of human beings ${ }^{(21)}$. The results of the study on-screen suggest that the invisibility resulting from conceptions centered on the biological aspect stems from the few experiences of care for people with disabilities and the lack of knowledge of CHAs about who these users are and how they need to be assisted.

In addition, the invisibility of particularities is evidenced when CHAs do not conceive differences between people with disabilities and without disabilities. By disregarding the particularities inherent to people with disabilities, access to care for this specific population is limited, and there is a risk that their needs will not be fully met ${ }^{(21)}$.

Such aspects leave disabled individuals in a vulnerable situation, as they have not guaranteed the principle of equity, which seeks to reduce socioeconomic differences in access to health services concerning $\mathrm{PHC}^{(22)}$. This vulnerability is aggravated by the fact that they live in a rural setting, and also because the social determinants in this scenario are not considered ${ }^{(23)}$.

The expanded view of professionals can help to meet the principle of equity. To this end, it is necessary for $\mathrm{PHC}$ professionals to be made aware of the importance of recognizing the multiple vulnerabilities of people with disabilities, providing differentiated access according to their specific needs ${ }^{(21)}$. In this sense, the work shared by different PHC professionals has been identified as a strategy for more qualified, expanded, and effective health care $^{(24)}$. 
In addition to these conceptions, the incipient knowledge of public policies aimed at people with disabilities was also identified, since the CHAs mostly cited one policy in their speeches, ignoring the existence of the others. This aspect affects health promotion and prevention actions, as well as access to existing rights for these individuals. This weakness can be due to the inadequacy or lack of training for professionals and the lack of discussion, mainly about the promotion of the health of people with disabilities ${ }^{(18)}$.

The lack of training and preparation of CHAs to work with people with disabilities was also evidenced in this study. In this regard, a study carried out to evaluate $\mathrm{CHA}$ learning through training on knowledge and skills to conceptualize, identify, and register people with disabilities obtained satisfactory results ${ }^{(18)}$. This finding reinforces the need for permanent education for these professionals so that they have subsidies to identify and assist people with disabilities in rural settings, considering their needs.

The CHAs also reveal the lack of support from other professionals within their area of coverage to provide service to people with disabilities. This fact indicates that agents feel the need to act in an intersectoral way to meet the needs of this population. Considering the social model of disability, which aims to break the biomedical view of disability, which restricts its understanding of injuries and impairments of the body, public policies aimed at people with disabilities cannot focus solely on the bodily/ biological aspects of these individuals ${ }^{(25)}$.

From this perspective, it is necessary to organize and operate the health care network from the perspective of the social model of disability. In other words, professional efforts must enable these individuals not only to overcome physical limitations but also to increase the quality of life, leisure, education, and work prospects so that they are guaranteed the right to live with dignity.

A study shows that health professionals who work in a rural context perceive people with disabilities from three pillars: the pathological body, functional disability, and limited social participation. The center of attention is based on the biomedical model with a tendency to the social, and health actions are directed to body changes ${ }^{(13)}$. This condition was evidenced in the present investigation, when the participants mentioned the need to use devices for the functions and activities of daily living and the need to attend, for example, the APAE, an institution where they are offered, among others, education, psychology and physiotherapy services and in which people with disabilities can develop their social aspects.

This same study reveals that health professionals have difficulties working with people with disabilities. They recognize the need and the importance of intersectoral work, identify the Núcleo de Apoio a Saúde da Família (NASF -Family Health Support Center) as a support for their actions, and note that there are also barriers for this service to be provided in a rural context. The lack of transportation to take the NASF team to health services in rural areas is an obstacle to the development of intersectoral actions ${ }^{(13)}$.

Within the scope of SUS, the Health Care Network for People with Disabilities comprises Primary Care, Specialized Care and Urgency and Emergency Hospital Care, and these offer services regulated by protocols and interconnected flows. In Specialized Care, the Centros Especializados de Reabilitação (CER-Specialized Rehabilitation Centers) serve different types of disability with interdisciplinary teams. The CER articulates the different points of the SUS care network ${ }^{(26)}$.
In this perspective, the organization of the Health Care Network for People with Disabilities involves the identification of the disability by the health sector and referral to CERs, based on a referral and counter-referral system. However, flows are not organized, and people with disabilities go through different services to obtain assistance, which often reveals the disarticulation of the network, which becomes an organizational barrier ${ }^{(27)}$. In this study, some professionals suggest the need to strengthen the Care Network for people with disabilities, especially aimed at rural communities to expand access and accessibility to services.

The concept of access and accessibility helps to understand the barriers faced by families of people with disabilities. For Starfield(28), accessibility is how the individual arrives at services, and access is how the person experiences attention at services. Accessibility is a condition of a health unit that is essential to pay attention to first. It is related to a condition of the structure as a place of care and availability for the use of services in order to provide better health conditions for the individual. Accessibility can be measured by identifying barriers to access, such as geographic, financial, and organizational barriers.

Therefore, comprehensive health care for people with disabilities is made difficult by the fear of families and by the geographical distances between services and rural settings, which in this study were found to be a barrier to access. The family's fear of taking people with disabilities to other services is based on their belief that family members are better able to provide support and attention to these users ${ }^{(29)}$.

Another difficulty encountered by people with disabilities who live in the rural context in the search for health care is access to the urban setting. Regarding this finding, we emphasize that access to health corresponds to the easy transportation of the population from the urban area due to the logistic organization. On the contrary, the rural area often does not have adapted transportation for this population, who need to move from home to the health unit, mainly in the rehabilitation process ${ }^{(13)}$.

In addition to geographic distances ${ }^{(30)}$, studies also point out other barriers faced by people with disabilities in rural settings to seek health care. Among these are the information and financial barriers ${ }^{(12)}$, as well as the limited supply of services and lack of professionals ${ }^{(23)}$. The economic conditions of people with disabilities and their families, as well as the difficulty of transportation, reinforce their isolation in rural settings, as they hinder access to care services. The lack of financial resources to pay for transportation is also reported in another study ${ }^{(30)}$.

The data meet the concept of people with disabilities presented by the Convention on the Rights of Persons with Disabilities, which is based on the social model of disability. This concept advances in the sense of articulating disability with social and political elements, with different social markers, such as race, gender, generation, and social class, which limit the concrete participation of people with disabilities in society ${ }^{(31)}$.

The marker "social class" is present in the results of the present investigation when the participants point out the restricted socioeconomic conditions of the families, who possibly do not have their own/individual means of transport to take their disabled family members to the services. Furthermore, they often do not have the financial resources to be able to pay for public transport, in cases where it exists in the territory. 
One of the forms of social protection for people with disabilities and their families, whose poverty makes them vulnerable, is the obtaining of the Benefício de Prestação Continuada (BPC - Continuing Cash Benefit), offered by Social Assistance. This benefit impacts the lives of people with disabilities and their families, as it provides access to the consumption of goods considered essential for survival, such as food, health treatment, expenses with house maintenance and clothing. In addition, obtaining the BPC promotes an increase in the social and financial independence of people with disabilities and their families, contributing to the development of the notion of autonomy and citizenship ${ }^{(32)}$.

To obtain the BPC, the disabled persons and their family must access health, social assistance, and social security services, which refers to the need for articulated and cooperative inter-sector work. It is necessary to prove a per capita income of less than a quarter of the salary, long-term impediments of physical, mental, intellectual or sensory nature, which, related to different barriers, can prevent the participation of these people in society. For that, they will have to be attended by health and social assistance professionals to evaluate and forward the request to be carried out at the Instituto Nacional de Seguro Social (National Social Security Institute). In this process, the vulnerability of the applicants increases the barriers generated by the lack of information on the ways to obtain the BPC ${ }^{(33)}$.

The difficulty of obtaining this benefit due to accessibility barriers related to the geographical distance of people with disabilities living in the rural scenario is compounded by the disarticulation of the sectors of social assistance, health, and social security. This fact often causes these people and family members to wander between sectors to obtain such a right.

\section{Study Limitations}

As a limitation, there are characteristics related to qualitative studies, which makes it difficult to generalize the results. Thus, we recommend the development of studies with an interventional approach, aiming to propose strategies to face the barriers that prevent comprehensive care for people with disabilities living in rural settings.

\section{Contributions to the nursing field}

When studying people with disabilities in rural areas under the perspective of $\mathrm{CHAs}$, their invisibility and barriers in rural settings are glimpsed. Thus, these results allow nursing professionals and the health team to rethink their practice, so that it is possible to develop strategies to overcome these barriers, aiming to produce, in this context, comprehensive care for people with disabilities.

\section{FINAL CONSIDERATIONS}

The study identified weaknesses and barriers make people with disabilities living in rural settings, invisible and distant from comprehensive and equitable health care. The weaknesses are related to the unpreparedness of $\mathrm{CHAs}$ and the inefficient qualifications to serve this population. The barriers to seeking comprehensive care for people with disabilities living in rural settings are particularly physical, economic, geographical and infrastructural.

Thus, a profound change is necessary in the sense of spreading welcoming practices so that the attention to people with disabilities in rural settings has their needs fully met. Seeking to bring public health policies closer to the particular reality that is outlined in rural settings.

\section{FUNDING}

Work financed by the call for submissions of FAPERGS/MS/ CNPQ/SESRS No. 03/2017 - Research program for SUS: shared management in health PPSUS - 2017.

\section{REFERENCES}

1. Organização Mundial da Saúde (OMS). World report on disability [Internet]. Genebra: OMS; 2011 [cited 2019 Jan 7]. 350 p. Available from: www.who.int/disabilities/world_report/2011/en/

2. Instituto Brasileiro de Geografia e Estatística (IBGE). Nota técnica 01/2018: Releitura dos dados de pessoas com deficiência no Censo Demográfico 2010 à luz das recomendações do Grupo de Washington [Internet]. Brasília (DF); IBGE; 2018.

3. Ministério da Saúde (BR) Decreto n 6.949, de 25 de agosto de 2009[Internet]. Brasília: Ministério da Saúde; 2009 [cited 2019 Jan 23]. $72 p$. Available from: http://www.planalto.gov.br/ccivil_03/_ato2007-2010/2009/decreto/d6949.htm

4. Ministério da Saúde (BR), Secretaria de Atenção à Saúde. Política Nacional de Saúde da Pessoa Portadora de Deficiência [Internet]. Brasília: Ministério da Saúde; 2008 [cited 2019 Jan 23]. 72p. Available from: http://bvsms.saude.gov.br/bvs/publicacoes/politica_nacional_saude_ pessoa_deficiencia.pdf

5. Moodley J, Ross E. Inequities in health outcomes and access to health care in South Africa: a comparison between persons with and without disabilities. Disabil Soci. 2015;30(4):630-44. doi: 10.1080/09687599.2015.1034846

6. Ministério da Saúde (BR), Secretaria de Atenção à Saúde. Política nacional de saúde da pessoa com deficiência [Internet]. Brasília: Ministério da Saúde; 2010 [cited 2019 Feb 03]. 12 p. Available from: http://bvsms.saude.gov.br/bvs/publicacoes/politica_nacional_pessoa_com_ deficiencia.pdf

7. Ministério da Saúde (BR), Portaria no 793, de 24 de abril de 2012. Institui a Rede de Cuidados à Pessoa com Deficiência no âmbito do Sistema Único de Saúde[Internet]. Brasilia; 2012 [cited 2019 Ouc 20]. Available from: http://bvsms.saude.gov.br/bvs/saudelegis/gm/2012/ prt0793_24_04_2012.html 
8. Presidência da República (BR). Lei no 13.146, de 6 de julho de 2015. Institui a Lei Brasileira de Inclusão da Pessoa com Deficiência (Estatuto da Pessoa com Deficiência)[Internet]. Brasília; 2015 [cited 2019 Oct 20]. Available from: http://www.planalto.gov.br/ccivil_03/_ato20152018/2015/lei/l13146.htm

9. Dassah E, Aldersey H, McColl MA, Davison C. Factors affecting access to primary health care services for persons with disabilities in rural areas: a "best-fit" framework synthesis. Glob Health Res Policy. 2018;3(36):1-13. doi: 10.1186/s41256-018-0091-x

10. United Nations General Assembly (UNGA). Transforming our world: the 2030 Agenda for Sustainable Development [Internet]. New York: UNGA; 2015 [cited 2019 Feb 05]. 41 p. Available from: https://sustainabledevelopment.un.org/post2015/transformingourworld

11. Marques MIM. O conceito de espaço rural em questão. Terra Livre[Internet]. 2002 [cited 2019 Oct 20];18(19). Available from: https://www. agb.org.br/publicacoes/index.php/terralivre/article/view/160/148

12. Neille J, Penn C. Beyond physical access: a qualitative analysis into the barriers to policy implementation and service provision experienced by persons with disabilities living in a rural context. Rural Remote Health[Internet]. 2015 [cited 2019 Feb 09];15:3332. Available from: https:// www.rrh.org.au/journal/article/3332

13. Ursine BL, Pereira EL, Carneiro FF. The health of people with disablility living in rural areas: what do Basic Health Care workers say? Interface. 2018;22(64):109-20. doi: 10.1590/1807-57622016.0666

14. Ayres JRCM. Organização das ações de atenção à saúde: modelos e práticas. Saúde Soc. 2009; 18(Supl 2):11-23. doi: 10.1590/ S0104-12902009000600003

15. Pinto AGA, Palácio MAV, Lôbo AC, Jorge MSB. Vínculos subjetivos do agente comunitário de saúde no território da Estratégia Saúde da Família. Trab Educ Saúde. 2017;15(3):789-802. doi: 10.1590/1981-7746-sol00071

16. Morosini MV, Fonseca AF. Community workers in Primary Health Care in Brazil: an inventory of achievements and challenges. Saúde Debate. 2018;42(spe1):261-274. doi: 10.1590/0103-11042018S117

17. Baptistini RA, Figueiredo TAM. Community health agents: the challenges of working in the rural area. Ambient Soc. 2014;17(2):53-68. doi: $10.1590 / \mathrm{S} 1414-753 \times 2014000200005$

18. Maia ER, Pagliuca LMF, Almeida PC. Learning of community health agent to identify and register disabled people. Acta Paul Enferm. 2014;27(4):326-32. doi: 10.1590/1982-0194201400055

19. Minayo MCS. O desafio do conhecimento. 14 ed. São Paulo: Hucitec; 2014. 406 p.

20. Minayo MCS. Amostragem e saturação em pesquisa qualitativa: consensos e controvérsias. Rev Pesqu Qualit[Internet]. 2017 [cited 2019 Feb 09];5(7):1-12 Available from: https://editora.sepq.org.br/index.php/rpq/article/view/82/59

21. Pessalacia JDR, Ribeiro IKS, Rates CMP, Azevedo C, Braga PP. Experiências de acesso a serviços primários de saúde por pessoas com Síndrome de Down. Rev Enferm C-Oeste Min. 2015;5(3):1752-67. doi: 10.19175/recom.v5i3.1275

22. Andrade MV, Noronha K, Barbosa ACQ, Rocha TAH, Silva NC, Calazans JA et al. A equidade na cobertura da Estratégia Saúde da Família em Minas Gerais, Brasil. Cad Saúde Pública. 2015;31(6):1175-87. doi: 10.1590/0102-311X00130414

23. Dassah E, Aldersey H, McColl MA, Davison C. 'When I don't have money to buy the drugs, I just manage': exploring the lived experience of persons with physical disabilities in accessing primary health care services in rural Ghana. Soc Sci Med. 2018;214:83-90. doi: 10.1016/j. socscimed.2018.08.023

24. Matuda CG, Pinto NRS, Martins CL, Frazão P. Colaboração interprofissional na Estratégia Saúde da Família: implicações para a produção do cuidado e a gestão do trabalho. Ciênc Saúde Colet. 2015;20(8):2511-21. doi: 10.1590/1413-81232015208.11652014

25. Bampi LNS, Guilhem, D, Alves ED. Modelo social: uma nova abordagem para o tema deficiência. Rev Latino-Am Enfermagem. 2010;18(4):[09 telas]. doi: 10.1590/S0104-11692010000400022

26. Campos MF, Souza LAP, Mendes VLF. A rede de cuidados do Sistema Único de Saúde à saúde das pessoas com deficiência. Interface. 2015;19(52):207-10. doi: 10.1590/1807-57622014.0078

27. Pereira JS, Machado WCA. Referência e contrarreferência entre os serviços de reabilitação física da pessoa com deficiência: a (des) articulação na microrregião Centro-Sul Fluminense, Rio de Janeiro, Brasil. Physis. 2016;26(3):1033-51. doi: s0103-73312016000300016

28. Starfield, B. Atenção primária: equilíbrio entre necessidades de saúde, serviços e tecnologia. Brasília: UNESCO, Ministério da Saúde, 2002. $726 \mathrm{p}$.

29. Dezoti AP, Alexandre AMC, Freire MHS, Mercês NNA, Mazza VA. Social support to the families of children with cerebral palsy. Acta Paul Enferm. 2015;28(2):172-6. doi: 10.1590/1982-0194201500029

30. Munthali AC, Swartz L, Mannan H, MacLachlan M, Chilimampunga C, Makupe C. "This one will delay us": barriers to accessing health care services among persons with disabilities in Malawi. Disabil Rehabil. 2019;26:1-8. doi: 10.1080/09638288.2017.1404148

31. Gesser M, Nuernberg AH, Toneli MJF. A contribuição do modelo social da deficiência à psicologia social. Psicol Soc[Internet]. 2012 [cited 2019 Nov 12];24(3):557-66. Available from: http://www.scielo.br/pdf/psoc/v24n3/09.pdf

32. Santos WR. Deficiência e BPC: o que muda na vida das pessoas atendidas?. Ciênc Saúde Colet 2011;16(Suppl 1):787-96. doi: 10.1590/ S1413-81232011000700009

33. Vaitsman J, Lobato LVC. Benefício de Prestação Continuada (BPC) para pessoas com deficiência: barreiras de acesso e lacunas intersetoriais. Ciênc Saúde Colet. 2017;22(11):3527-36. doi: 10.1590/1413-812320172211.20042017 